\title{
マイクロメーターサイズの粒子配列
}

\author{
不 動 寺 浩*, 小林 幹 彦* \\ 江 頭 満*, 新 谷 紀 雄*
}

\section{The Arrangement of Micrometer-sized Powder Particles by Electron Beam Drawing}

\author{
by
}

\author{
Hiroshi FUDOUZI ${ }^{\dagger}$, Mikihiko KOBAYASHI ${ }^{\dagger}$ \\ Mitsuru EGASHIRA ${ }^{\dagger}$ and Norio SHINYA ${ }^{\dagger}$
}

\begin{abstract}
The creation of new advanced functional materials is anticipated by assembling micrometer-sized particles which have various kinds of functions. In this work, a new concept for assembling powder particles is proposed, and preliminary research results of this assembling are reported. The process for assembling is as follows: (1) electrified patterns are drawn on calcium titanate substrate using electron beam drawing and observed by the voltage contrast method, (2) the substrates are dipped into solvent in which spherical silica particles $(5 \mu \mathrm{m}$ in diameter $)$ are dispersed, and (3)the particles are adhered to the electrified patterns under suitable conditions. The amounts of adhered particles are influenced by the density of particles in the solvent, the dose electron density of electrification and dipping time of the substrate into the solvent. $B y$ using adequate values of these parameters, comparatively clear silica particle arrangements on the electrified patterns were obtained.
\end{abstract}

Key Words : Particles Assembly, Electron Beam Drawing, Electrification, Voltage Contrast, Spherical Silica

\section{1. 緒 言}

近年, 粉体粒子を複合化しその機能をも複合化・高 度化する研究" ${ }^{1}$ が盛んに行われている。これは粉体粒 子の持つ有用な機能をそのまま活用することに加え， 粉体粒子の機能を粉体粒子のア七ンブル体の材料に反 映し，材料を多機能化 ・高度化する有力な手段として 期待されているからである。粉体粒子の持つ機能を, 意図的に, 効果的に, さらにシステム化して材料に持 たせようとすると, 粉体粒子を単に混合させるだけで

\section{5年 8 月 31 日受付}

粉体工学会第31回夏期シンポジウム(1995年 8 月, 函南)にて発表

* 科学技術庁金属材料技術研究所

( (305 茨城県つくば市千現 1-2-1) TEL. 0298-53-1146

$\dagger$ National Res. Institute for Metals

(1-2-1, Sengen, Tsukuba-shi, Ibaraki 305)
はその目的を果たせないばかりでなく，粉体粒子自身 の持つ素機能をも活かすことができないであろう。そ こで必要となるのが, 粉体粒子を設計どおりに, 自由 自在に配列する技術である。そのために, 著者らは粒 子アセンブル2゙なる新しい視点に立った材料創製の概 念を提案し, その粉体粒子配列化に主眼を置いたプロ セス技術に関する研究を行ってきだ)。

本報告では，その一環として行っている電子ビーム を利用した粒子配列において, 粒子を目的の位置に配 列するのに必要な制御因子とその影響範囲を明かに し, 粒子配列の指針を得るための検討を行った。

\section{2. 実験方法}

\section{1 粒子配列の概念}

マイクロメータサイズの粒子を基板上に設計に治っ 
て配列させる手段として，電子ビ一ムを用い，電子ビ 一八描画を利用する方法 2゙を著者らは提案している。 その概念は, 適切な基板を用い, 適切な条件で電子ビ 一ム描画を行えば，電子ビームを照射された部分のみ 帯電され，電子ビ一ム描画像はそのまま帯電像となる。 带電した部分は，電界を生じるから，粒子を近付けれ ば，クーロンカあるいはグレーデイエントカにより， 帯電部分に付着する。適正に粒子が供給されれば, 带 電像上に粒子が配列し, 带電像は粒子配列像となり得 る。この粒子配列像を積極的に利用し，マイクロデバ イス作製やさらに 3 次元配列へと拡張し，高度な機能， 例えばインテリジェント材料 ${ }^{4}$ への道を切り開こうと 寸るのが，最終的な目標である。このような粒子配列 の概念をFig. 1に示す。

マイクロデバイスや材料創製へと発展されるには, 粒子が目的の位置に正確に付着すること, 複数種類の 各種多様な機能を持った粒子を任意に配列できるこ と，これら粒子を基板に固定化し，その上にさらに粒 子を積層配列化し，3次元化することなど越えるべき 課題は多い。

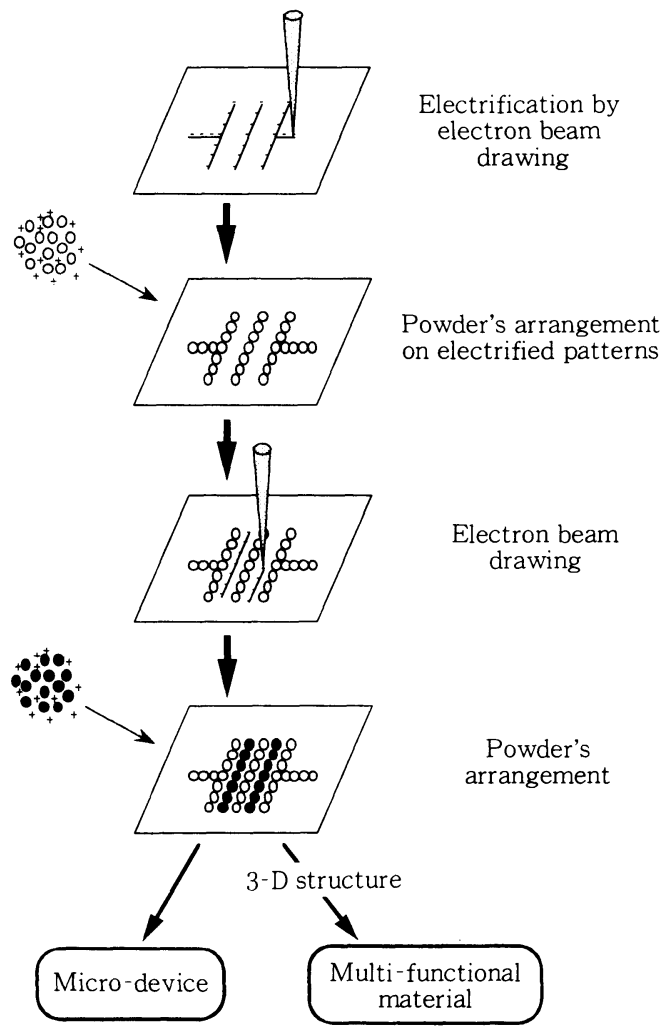

Fig. 1 Conceptual process for powder particles' assembly assisted by electron beam drawing.

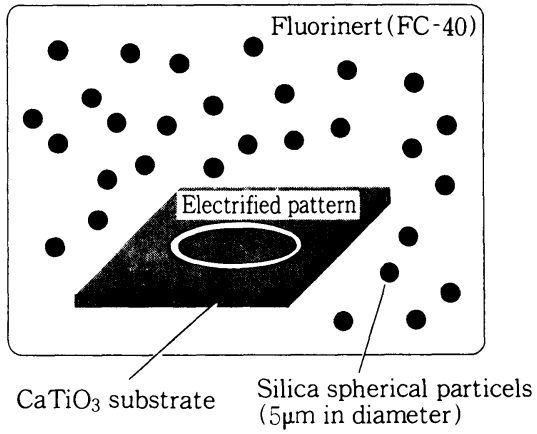

Fig. 2 Process of particles' supply and adhesion on electrified pattern

本研究では，この粒子配列の概念を実現させるため の取組の第一歩として, 誘電体の基板上へ電子ビーム 帯電像を得ること，その帯電像へモデル粒子を付着配 列させ，带電像を粒子配列像とし，視覚化し，確認す ることを目的とした。基板の带電像部分への粒子供給 方法としては，絶縁性の溶媒中へ，粒子を分散させ， この液中に基板を浸漬させるFig. 2に示す方法光を採 用した。

\section{2 軋子ビーム描画}

\section{2.1 基 板}

電子ビーム描画を行う基板として, チタン酸カルシ ウム $\left(\mathrm{CaTiO}_{3}\right.$; 京七ラ社製, $\left.\mathrm{SD}-100 \mathrm{~L}\right)$ を用いた。使 用した $\mathrm{CaTiO}_{3}$ 基板は比誘電率 $\left(\varepsilon_{r}\right)$ が 100 と大きく，鮮 明な帯電像を得やすいこと, 体積固有抵抗 $(\rho)$ は $10^{12} \Omega$ $\cdot \mathrm{m}$ と大きく, 帯電の劣化や損失を低く抑えられるこ と, 鏡面 $(R a<0.02 \mu \mathrm{m})$ の滑らかな表面を持った基板 が供給されていることなどから選択した。このチタン 酸カルシウム基板を湿度の影響を避けるため, シリコ ーンオイル（東レダウコーニングシリコーン社製, SH-200)コーティング処理を行った。

\section{2.2 電子ビーム描画}

電子ビーム描画はCAD機能を付加した走查型電子 顕微鏡 $(\mathrm{SEM}$ ；トプコン社, SX-40A)を用いた。描画 条件として, 電子ビ一ムの加速電圧 $(E v)$ はチタン酸力 ルシウムの 2 次電子放出比が 1 以下で, 電子ビーム照 射に伴いマイナスに帯電する $5 \mathrm{kV}$ 以上の加速電圧領域 で行った。

電子ビーム描画に伴う带電像の観察は, 電位コント ラスト法 ${ }^{5}$ により行った。この方法は, 低加速電圧の 電子ビーム走査により基板上の带電の違いを 2 次電子 像のコントラストとして観察する方法である。帯電像 を得るための 1 次電子ビーム走查は $2 \mathrm{kV}$ 加速電圧で 行った。電位コントラストの強度分布を定量化して解 
析するため, 得られた 2 次電子像のネガフイルムを画 像入力装置(EPSON社製, GT-9000)を介してコンピ ュータ(Apple社製, Macintosh LC-630)に取り込ん だ。さらに,コンピュータ上で画像解析処理( Mac Scope)を行うことで電位コントラストの相対強度の 分布值を得た。

\section{3 帯電像への粒子付着プロセス}

モデル粒子として, 粒径サイズが $5 \mu \mathrm{m} の$ 単分散真球 状シリ力粒子(宇部日東化成社製, UF-510U) 使用 した。このシリカ粒子を絶縁性のフッ素系溶媒である フロリナート(住友3M社製, FC-40) 中へ投入し, 超 音波振動によりシリカ粒子老溶媒中へ分散させ, 粒子 分散液を調製した。

帯電像を形成した基板を電子ビ一ム描画後, 大気中 に取り出し，直ちにこの粒子分散液に浸漬した。粒子 分散液の温度は室温とし粒子分散液の粒子濃度は $10^{5}$ $\sim 10^{7}$ 個 $/ \mathrm{ml}$ の範囲で, 基板の浸漬時間は $2 \sim 50$ 秒の範 囲にわたり，粒子付着特性を調べた。粒子付着のた め, 粒子を分散させたフロリナート (FC-40, 沸点 : $\left.155^{\circ} \mathrm{C}\right)$ に基板を浸漬後, 引き上げた基板を低沸点のフ ロリナート $\left(\mathrm{FC}-72\right.$, 沸点: $\left.56^{\circ} \mathrm{C}\right)$ で洗浄し, 大気中で 自然乾燥した。

基板上に付着した粒子は金属顕微鏡(ニコン社製， OPTIPHOTO) 及びSEM $(2 \mathrm{kV})$ を用いて観察し, 付 着粒子数の計測を行った。

\section{3. 結果及び考察}

\section{1 帯電像の形成と観察}

Fig. 3 に電子ビームのEvが $15 \mathrm{kV}$ ，そして描画像の 描画単位当りの電子ビームのドーズ量 $(Q u)$ が $0.2 \mathrm{pC} /$ $\mu \mathrm{m}^{2}$ となる条件で形成した带電像の一例を示す。この

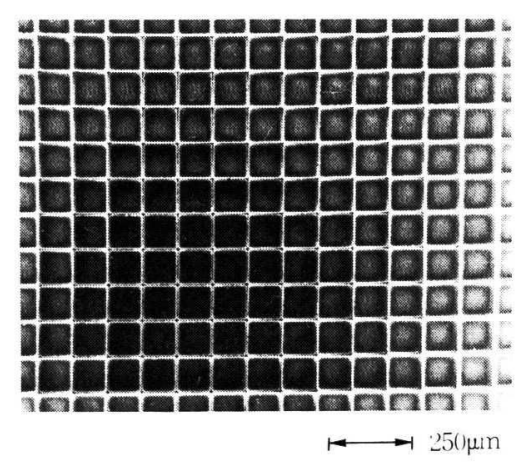

Fig. 3 Voltage contrast image of electrified pattern drawn on $\mathrm{CaTiO}_{3}$ substrate by $15 \mathrm{kV}$ electron beam. The image was observed by $2 \mathrm{kV}$ electron beam scan

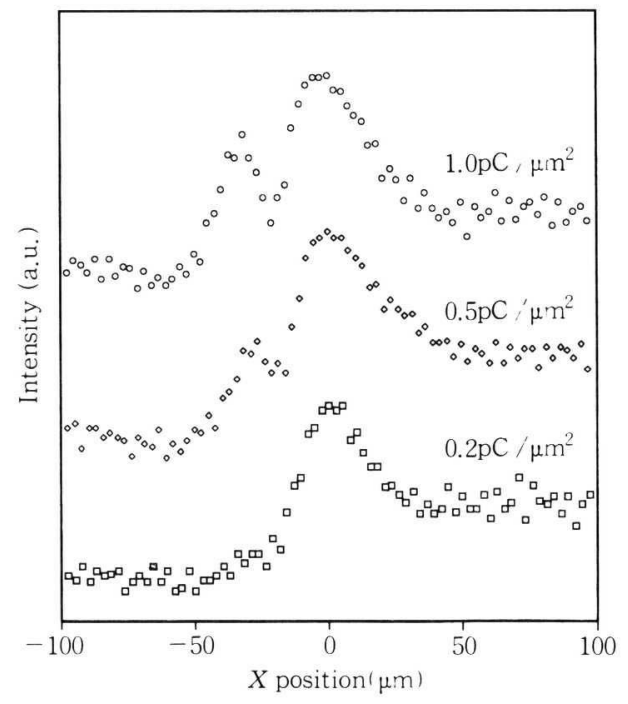

Fig. 4 Relationship between dose electron density and intensity profile of secondary electrons in electrified pattern measured by voltage contrast method.

試行的に得た直交格子は, 線幅 $1 \mu \mathrm{m}$ で描画している が, 電位コントラスト法で解析した带電像の直交格子

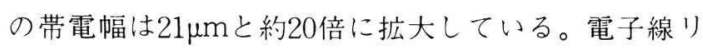
ソグラフィーにおいても, 描画線幅よりレジストの露 光幅が広がるのが問題となっているが, それと比べ拡 大幅は一層大きい。このような拡大は, $\mathrm{CaTiO}_{3} に$ 带 電させた電荷が抵抗の低い表面部において拡散し, 表 面部の带電領域が拡大したものと考元られる。この帯 電領域の拡大は, 電子ビ一ム描画時の $Q u$ が多くなる ほどに顕著となり,また带電線内に分極が見られ带電 ピークが2本に分かれる。

Fig. 4 は $E v$ が $15 \mathrm{kV}, Q u$ が1.0, 0.5 及び $0.2 \mathrm{pC} / \mu \mathrm{m}^{2}$ で電子ビーム描画し, 電位コントラスト法で得た帯電 像を横断するコントラストの画像解析結果である。Fig. 4 から帯電像の拡大や線画の分裂を防ぐためにはQuを $0.5 \mathrm{pC} / \mu \mathrm{m}^{2}$ 以下とする必要があることが分かる。

带電像の拡大化や線画の分裂のメカニズムについて は今後明かにしていきたい。帯電像は, 線幅の広がり はあるものの適切な条件とすれば, 描画像通りの比較 的鮮明な带電像として観察することが可能であること が分かった。

\section{2 粒子像の形成に及ぼす影響因子}

帯電像への粒子の付着は, 粒子を分散させた溶媒中 に基板を浸漬して行った(Fig. 2)。この粒子像形成に 影響する因子として, 带電像への付着速度に関するも のと粒子像の鮮明さを損なう帯電像以外への付着速度 
に関するものの 2 面から検討した。その結果, 直接的 な因子として, 粒子供給に関する溶媒中の粒子濃度と 基板の溶媒中への浸漬時間, そして溶媒中の粒子を誘 引し捕捉する帯電像の帯電量を取り上げ, それらの影 響を調べた。

\section{2.1 溶媒中の粒子濃度 $\left(C_{\mathrm{N}}\right)$ の影響}

溶媒中の粒子濃度の選択を行うため, まず粒子像の 鮮明さを損なうことになる未帯電の $\mathrm{CaTiO}_{3}$ 基板に付 着する粒子数を調べた。各濃度の溶液への基板の浸漬 時間を，50秒に一定とした。付着した粒子数を数え， 単位面積当りの付着粒子数 $\left(N_{\mathrm{S}}\right)$ を求めた。Fig. 5 に その結果を示す。

次に，带電像を形成した基板をFig. 5の中の(a), (b)に相当する $C_{N}$ の粒子分散液に 50 秒間浸した。結果 をFig. 6 のそれぞれ $(\mathrm{a})$ 及び(b)に示す。帯電像は $E v$ が $15 \mathrm{kV}, Q u$ が0.25pC / $\mu \mathrm{m}^{2}$, で直径 $200 \mu \mathrm{m}$ のーク ルを描画線幅 $1 \mu \mathrm{m}$ で電子ビーム描画した。Fig. 6(a) の $C_{\mathrm{N}}$ で帯電像への粒子の付着は全く見られない。一 方, Fig. 6(b)のC が, 帯電していない部分にも粒子の付着がかなり見ら れる。これらの結果より $C_{\mathrm{N}}$ は粒子の付着に大きく影 響し, 鮮明な粒子像を得るための重要な因子であるこ とが分かる。Fig. 5 より $C_{\mathrm{N}}$ を例えば $10^{6}$ 個 $/ \mathrm{m} l$ 程度と すると, 帯電像以外の部分への粒子付着を $1 / 3$ に減ら すことができる。この余分の粒子付着が $1 / 3$ となれ ば，少なくとも視覚的なノイズ感はかなり緩和される。 しかし， $C_{\mathrm{N}}$ を $10^{6}$ とすると帯電像への粒子付着数が減 少するので, その分带電条件等で補う必要がある。

\section{2.2 帯電像形成時の $\boldsymbol{E} v$ と $\boldsymbol{Q u}$ の影響}

帯電像の形成をEvが5〜20kVの範囲で 4 段階，Quを Fig. 4 の結果を踏まえ $0.5 \mathrm{pC} / \mu \mathrm{m}^{2}$ 以下とし，4段階変

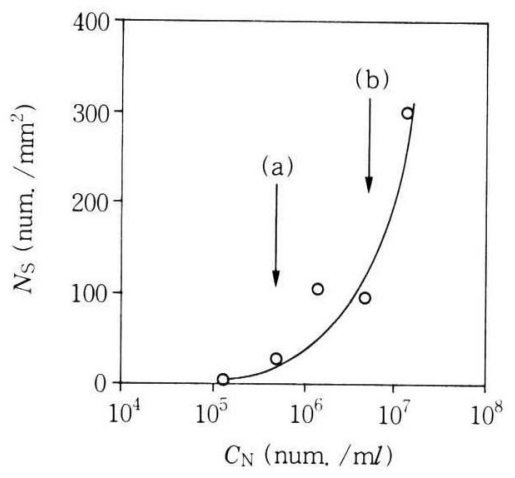

Fig. 5 Relationship between particle concentration in non-polar solvent and silica particle density adhered to substrate

(Dipping time : 50s)
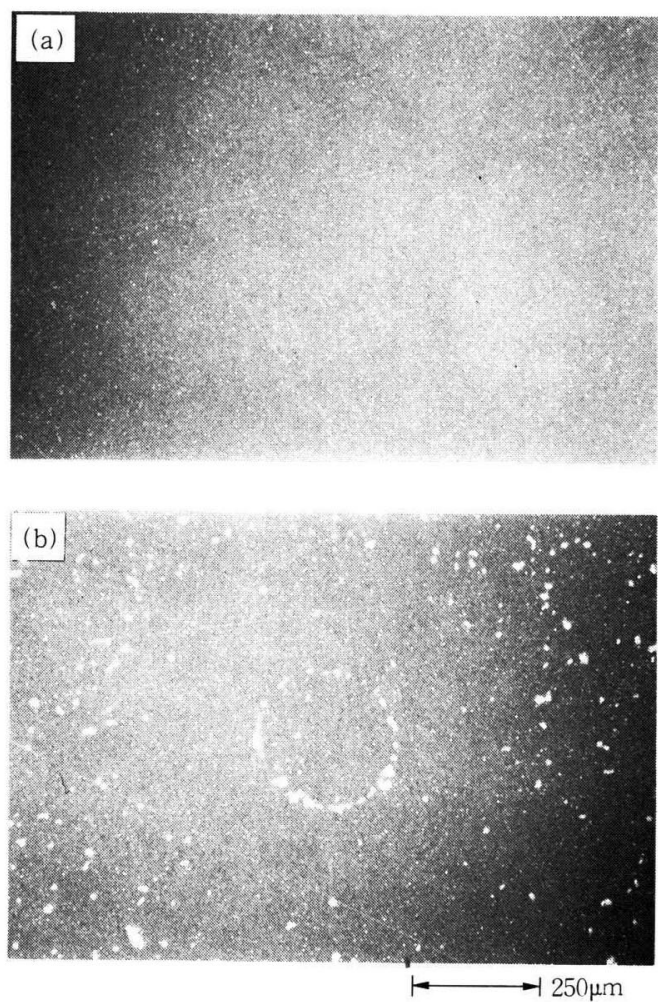

Fig. 6 Optical micrographs of silica particles adhered to electrified patterns on $\mathrm{CaTiO}_{3}$. $\left(C_{\mathrm{N}}\right.$ : (a) $5 \times 10^{5}$ num. $/ \mathrm{ml}$, and (b) $5 \times 10^{6}$ num. $/ \mathrm{ml}$ )

化させ, 直径 $200 \mu \mathrm{m}$ のサークルを電子ビ一ム描画した。 この基板を $C_{\mathrm{N}}$ が $1.4 \times 10^{6}$ 個 $/ \mathrm{m} l$ の粒子分散液に 20 秒 間, 浸漬した。

帯電像に付着した粒子数を数え, その結果をFig. 7 に示す。粒子付着数は実験範囲，すなわち $0.5 \mathrm{pC} / \mu \mathrm{m}^{2}$ までは, $Q u に$ 比例して, 描画像への付着粒子数 $\left(N_{\mathrm{E}}\right)$ は増加する。一方, $E v$ の影響は単調ではなく, $15 \mathrm{kV}$

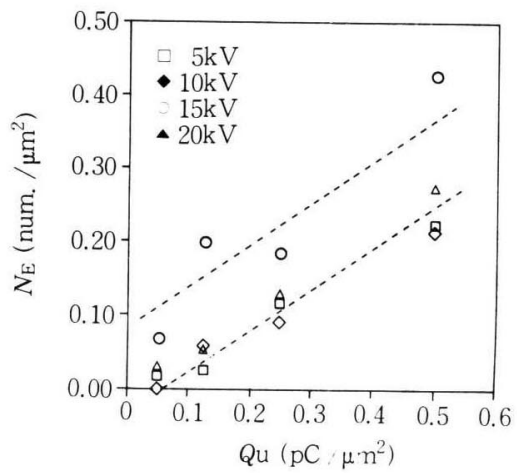

Fig. 7 Relationship between dose electron density and silica particle density adhered to electrified pattern 
において，特異的に $N_{\mathrm{E}}$ が大きくなっているが，その前 後の5，10及び20kVでは同じ程度である。

\section{2.3 基板の浸漬時間}

基板上への粒子供給量は, 粒子分散液中での基板の 浸漬時間に影響を受ける。そこで基板の浸漬時間と $N_{\mathrm{E}}$ の関係を調べたのがFig. 8である。带電像は長さ $1000 \mu \mathrm{m}$ のインで, Evが15kVで描画した。浸漬時間 に対し描画時のQuが $0.2,0.5 \mathrm{pC} / \mu \mathrm{m}^{2}$ ともほぼ比例的 にN $N_{\mathrm{E}}$ が増加する。これは带電像の持つ静電気力範囲 に粒子がほぼ一定速度で浮遊してくるためと考えられ る。また，Quを小さくすると同じ $N_{\mathrm{E}}$ を得るためによ り長い浸漬時間が必要となる。

帯電像を構成する電荷は時間の経過と共に減衰す る。この帯電像の静電気力の減衰がどの程度であるか 調べた。Evが $15 \mathrm{kV}$ で描画後, 基板をSEMから取り出 し，基板上に描画されているFig. 3に示す直交格子の 带電領域における電荷の減衰を表面電位計で測定し た ${ }^{6)}$ 。測定は恒温恒湿状態(温度: $22^{\circ} \mathrm{C}$, 相対湿度 : $7 \%$ )で行ない，経過時間はSEMより取り出した時間 を始点とした。Fig. 9にその表面電位の変化を示す。 これより, 表面電位は10000秒にわたってほとんど変 化しないことが分かった。粒子付着操作を行っている フロリナート中では電荷の減衰は更に少ないと考えら れるから, 带電像の持つ静電気の劣化はあまり考虑し ないでよいといえる。

\section{3 粒子配列の例}

前項で得られた比較的適正と考えられた条件，例え ば, Evが $15 \mathrm{kV}, Q u: 0.5 \mathrm{pC} / \mu \mathrm{m}^{2}, C_{\mathrm{N}}: 1.4 \times 10^{6}$ 個 / $\mathrm{ml}$, 浸漬時間 : 20 秒でモデル粒子の $5 \mu \mathrm{m}$ のシリカ粒子 を配列させた例をFig. 10に示す。電子ビーム带電像 に沿って，一応粒子が配列しているものの，配列に欠

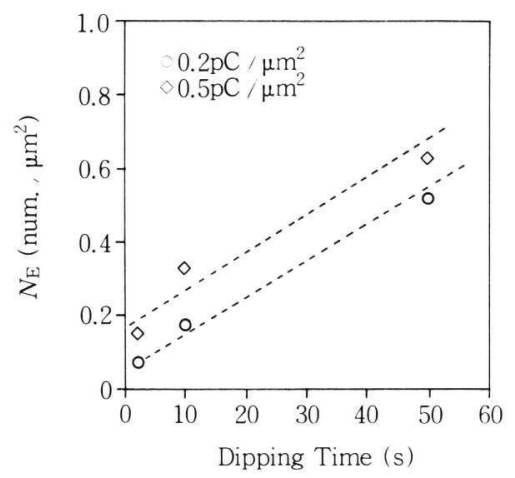

Fig. 8 Relationship between dipping time of substrate into solvent and silica particle density adhered to electrified pattern.

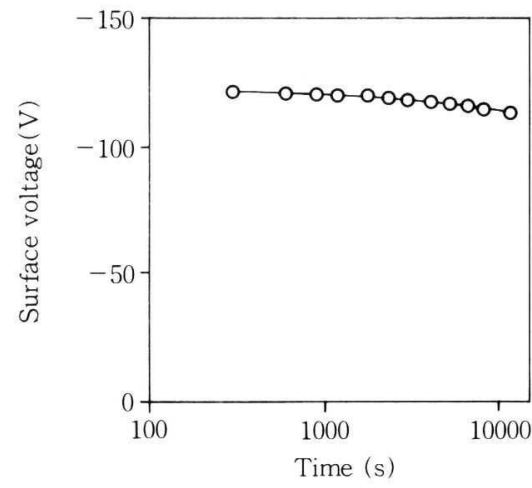

Fig. 9 Change in surface voltage of electrified pattern with time of exposure to air

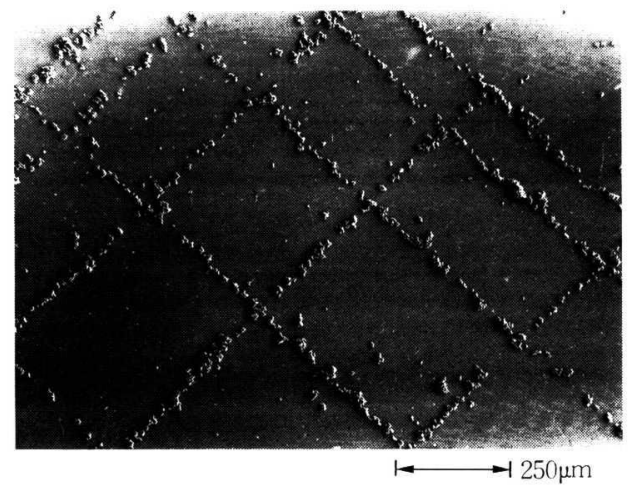

Fig. 10 SEM image of arranged silica particles on $\mathrm{CaTiO}_{3}$ substrate. ( $\mathrm{Ev}: 15 \mathrm{kV}, \mathrm{Qu}: 0.2 \mathrm{pC} / \mathrm{mm}^{2}$, $\left.C_{\mathrm{N}}: 1.4 \times 10^{6} \mathrm{Num} . / \mathrm{m} /, 20 \mathrm{~s}\right)$

損や粒子の凝集部分が見られ, 滑らかな連続線画像と はなっていない。また未带電部分の粒子付着はかなり 防げたものの一部にノイズとして付着している。

また，Fig. 11は複数種類の粒子を配列させること を意図して，試みた例である。この例ではEvが $15 \mathrm{kV}$, $\mathrm{Qu}: 0.5 \mathrm{pC} / \mu \mathrm{m}^{2}, C_{\mathrm{N}}: 2 \times 10^{6}$ 個 $/ \mathrm{m} l$, 浸漬時間 : 120 秒でモデル粒子の $5 \mu \mathrm{m}$ の 2 種類のシリカ粒子(トクヤ マ社製，LS-50BF とLS-50WF) を配列させた。黒色 のシリカ粒子の带と白色のシリカの帯を約 $50 \mu \mathrm{m}$ の間 隔で並べることができている。

粒子配列体をデバイスや材料創製に役立てるには， さらに鮮明な粒子配列像とすることや配列粒子の粒子 が連続的に配列し，久損を生じないことなど課題は多 w。

しかしながら本研究の予備的な検討により，粒子を アセンブルしていくことの可能性を見いだせたと考え たい。 


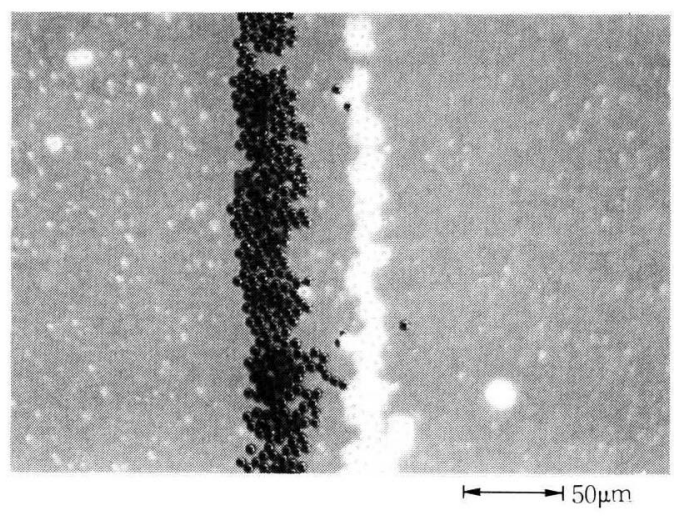

Fig. 11 Optical micrograph of two tones' lines composed of white and black sillica particles arranged on $\mathrm{CaTiO}_{3}$ substrate.

(Ev : $15 \mathrm{kV}, Q u: 0.1 \mathrm{pC} / \mu \mathrm{m}^{2}, C_{\mathrm{N}}: 2 \times 10^{6} \mathrm{num}$. / $\mathrm{ml}, 300 \mathrm{~s})$

(White:LS-50WF $(\phi 5 \mu \mathrm{m})$, Black:LS- $50 \mathrm{BF}(\phi 5 \mu \mathrm{m}))$
その上に粒子を付着させ，粒子配列像を得る技術の基 本的な概念を提案すると共に, 粒子配列像を実際に得 るため, 粒子分散液中に基板を浸漬する方法について の基本的な検討を行い次の結果を得た。

(1) $E v$ が $5 \mathrm{kV}$ 以上の電子ビーム描画により, マイナ スに帯電した帯電像が得られるが, 鮮明な帯電像とす るには描画時のQuを $0.5 \mathrm{pC} / \mu \mathrm{m}^{2}$ 以下とする必要があ り, 加速電圧を $15 \mathrm{kV}$ が適切である。

(2) 帯電像は $E v$ が $2 \mathrm{kV}$ の帯電ビーム走査により, 鮮 明な電位コントラスト像として観察できる。

（3）带電像への粒子付着に影響のある因子として, 浸漬する液中の粒子濃度, 带電条件, 浸漬時間を唡討 した本実験の条件下では, $C_{\mathrm{N}}$ が $10^{6}$ 個 $/ \mathrm{ml}$ オーダー, Quが $0.5 \mathrm{pC} / \mu \mathrm{m}^{2}$ 以下がよいと考え, 比較的鮮明な粒 子配列像を得ることができた。

\section{4. 結 言}

電子ビーム描画を用いて基板上に帯電像を形成し,

\section{Nomenclature}

$\varepsilon_{r} \quad$ : relative dielectric constant

$\rho \quad$ : volume resistance

$R_{a} \quad$ : center line average hight

Ev : accelerating electron voltage

$Q u$ : dose electron density

$C_{N}$ : concentration of particles in solvent
$(-)$

$(\Omega \cdot \mathrm{m})$

$(\mu \mathrm{m})$

(V)

$\left(\mathrm{pC} / \mu \mathrm{m}^{2}\right)$
$N_{S}$ : number of adhered particles on substrate

(number $/ \mathrm{mm}^{2}$ )

$N_{E}$ : number of adhered particles on electron beam drawing area

(number $/ \mu \mathrm{m}^{2}$ )

\section{References}

1) Koishi, M., : "Biryuushi Setsukei”, Kougyou Chousakai (1987)

2) Shinya, N., M. Egashira and H. Fudouzi : Proc. of 2nd Int. Conf. on Intelligent Materials, pp. 1142 1151, USA Virginia(1994)

3) Fudouzi, H., et al : Extended Abstracts of the 4th symp. on Intelligent Materials, pp.94 96, Japan, Tokyo(1995)
4) Science and Technology Agency, “The concept of Intelligent Materials and The Guidlines on R \& D Promotion", Japan, (1989)

5) Seiler, K., : J. Appl. Phys., 54, No. 11, pp. R1 R18(1971)

6) Uehara, T., : Proc. of the inst. of electrostatics jap., 13(4), pp.284 291(1989) 